\title{
"The moderating effect of shareholder features on dividend disbursement: evidence from Indonesia"
}

Novi Swandari Budiarso (D https://orcid.org/0000-0002-5832-0117

AUTHORS

R https://publons.com/researcher/2068888/novi-s-budiarso/

Winston Pontoh (D) https://orcid.org/0000-0003-3123-7919

R https://publons.com/researcher/2068901/winston-pontoh/

Novi Swandari Budiarso and Winston Pontoh (2018). The moderating effect of

ARTICLE INFO shareholder features on dividend disbursement: evidence from Indonesia. Investment Management and Financial Innovations, 15(3), 343-350. doi: 10.21511/imfi.15(3).2018.28

DOI http://dx.doi.org/10.21511/imfi.15(3).2018.28

RELEASED ON

Thursday, 27 September 2018

RECEIVED ON

Wednesday, 16 May 2018

ACCEPTED ON

Wednesday, 19 September 2018

\section{$(\mathrm{ccc}) \mathrm{EY}$-NC}

LICENSE

This work is licensed under a Creative Commons Attribution-NonCommercial 4.0 International License

JOURNAL

"Investment Management and Financial Innovations"

ISSN PRINT $1810-4967$

ISSN ONLINE $1812-9358$

PUBLISHER

LLC "Consulting Publishing Company "Business Perspectives"

FOUNDER

LLC "Consulting Publishing Company "Business Perspectives"

NUMBER OF REFERENCES

28

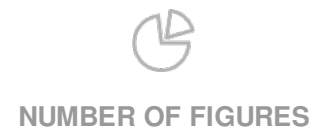

0
NUMBER OF TABLES

3

(C) The author(s) 2022. This publication is an open access article. 


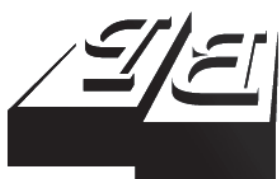

BUSINESS PERSPECTIVES

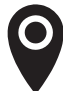

LLC "CPC "Business Perspectives" Hryhorii Skovoroda lane, 10, Sumy, 40022, Ukraine

www.businessperspectives.org

Received on: $16^{\text {th }}$ of May, 2018 Accepted on: $19^{\text {th }}$ of September, 2018

(c) Novi Swandari Budiarso, Winston Pontoh, 2018

Novi Swandari Budiarso, Lecturer, Faculty of Economics and Business, Sam Ratulangi University, Indonesia.

Winston Pontoh, Associate Professor, Faculty of Economics and Business, Sam Ratulangi University, Indonesia.

\section{(ㄷ)(1) $(8)$}

This is an Open Access article, distributed under the terms of the Creative Commons Attribution-NonCommercial 4.0 International license, which permits re-use, distribution, and reproduction, provided the materials aren't used for commercial purposes and the original work is properly cited.

\section{THE MODERATING EFFECT OF SHAREHOLDER FEATURES ON DIVIDEND DISBURSEMENT: EVIDENCE FROM INDONESIA}

\begin{abstract}
The objective of this study is to give an empirical evidence of relationship between features of ownership structures and dividend disbursement in context of bird in the hand and catering theories. The study uses 241 listed firms as the sample, which were drawn from Indonesia Stock Exchange during the period from 2010 to 2015. Under condition that dividend policy is not moderated by ownership features, dividend policy for firms with multi-institutional, single institutional, and state are fit in context of bird in the hand theory and catering theory. Under condition that dividend policy is moderated by ownership features, this study finds that dividend policy for firms with state ownership is not fit both in context of bird in the hand theory and catering theory. Specifically, the study finds that firms with features of: (1) multi-institutional, single individual, and public; (2) multi-institutional, multi-individual, and public; and (3) single institutional, and public are fit with bird in the hand theory. Furthermore, this study finds that catering theory is not fit for firms with basic features of multi-institutional and state ownership, but it is fit for firms with features of single institutional, single individual, and public ownership.
\end{abstract}

Keywords

JEL Classification dividend policy, ownership features, bird in the hand, catering

G35, G32, G41

\section{INTRODUCTION}

Generally, dividend policy by public firms empirically is one of some factors, which can trigger the movement of shares in capital market (Aharony \& Swary, 1980; La Porta, De Silanes, Shleifer, \& Vishny, 2000; Al-Yahyaee, Pham, \& Walter, 2011). Dreman and Lufkin (2000), and Baker and Wurgler (2007) prove that dividend is a better signal as a good news that affects the psychology of investors to react on firm shares in capital market. Baker and Wurgler (2004a) propose that dividend disbursement is a policy, which addresses whether firms should distribute the retained earnings to shareholders or not. Normally, firms decide to not distribute earnings, because they want to fund investment requirements or other interests (Budiarso, 2017).

Some empirical evidences show that the major theories as determinants of dividend disbursement are catering and bird in the hand. The studies of Baker and Wurgler (2004a, 2004b), Li and Lie (2006), Polk and Sapienza (2009), Hui and Li (2014), Pontoh (2015), and Budiarso and Pontoh (2016) emphasize that catering is the main cause for the firms to distribute earnings in form of dividend for shareholders in condition shareholders create higher demand on firm shares in capital market. Reversely, Modigliani and Miller (1958), Easterbrook (1984), Ozuomba, Anichebe, and Okoye (2016), and Reyna (2017) suggest that dividend as bird in the hand shall be distributed by firms with the 
aim to maximize the wealth of shareholders (Modigliani \& Miller, 1958; Easterbrook, 1984; Ozuomba, Anichebe, \& Okoye, 2016; Reyna, 2017). Furthermore, there are additional evidences that show that ownership features have relationship with dividend policy. The features of ownership are family ownership (La Porta, De Silanes, Shleifer, \& Vishny, 2000), state (Gugler, 2003; Lin, Chen, \& Tsai, 2017), institutional (Wei, Wu, Li, \& Chen, 2011; Reyna, 2017), and individual (Bøhren, Josefsen, \& Steen, 2012). The local study of Saerang and Pontoh (2016) shows that public firms in Indonesia have many features of ownership.

The objective of this study is to examine whether ownership features have moderating effect on determining dividend disbursement in assumptions of bird in the hand and catering theories. To meet this objective, the study uses return on equity and earnings per share as the proxy of bird in the hand, while share price used as the proxy to detect catering. Also, this study develops the types of ownership by Saerang and Pontoh (2016) in case to confirm the role of ownership features on dividend policy.

This study finds that ownership features play a significant role for firms with multi-institutional to distribute dividend, although it is not because of catering, while firms with single institutional as the basic feature mostly because of catering. Reversely, ownership features play an insignificant role in determining dividend policy. The further details for this study proceed as follows: section 1 reviews the relevant literatures, section 2 describes the research methods of this study, section 3 provides the results of analysis and discussion, and last section concludes.

\section{LITERATURE REVIEW}

Bird in the hand is normally used as a theory to explain the dividend policy. Easterbrook (1984) proves that wealth of shareholders improvement is the main reason, which underlies the bird in the hand theory. Easterbrook (1984) also explains that paying dividend is a better strategy to align the interests between shareholders and insiders. Bhattacharya (1979) and Easterbrook (1984) explain that dividends can be assumed as bird in the hand as long as the investors (or shareholders) do not re-invest the dividends or do not sell their shares in the capital market. The factor, which has close relationship with the concept of bird in the hand, is profitability and is considered as an indicator to amplify the dividend policy with the aim to improve the welfare of shareholders. The studies of Lintner (1956), Denis and Osobov (2008), and Farrukh, Irshad, Khakwani, Ishaque, and Ansari (2017) show that profitability is significant for public firms to determine their dividend policy.

Furthermore, Baker and Wurgler (2004a, 2004b) propose catering theory to explain firm dividend policy. Baker and Wurgler (2004a, 2004b) explain that catering theory focuses on a relationship between insiders and investors where firms shall distribute their dividends only when investors over- value their shares in capital market. Baker and Wurgler (2004a, 2004b) confirm that catering theory focuses on investor's psychology or sentiment where investors will react when firms announce dividend distributions in condition they are uninformed. This finding is similar with the findings of Dreman and Lufkin (2000), Li and Zhao (2008), Polk and Sapienza (2009), Pontoh (2015), and Budiarso and Pontoh (2016). Li and Lie (2006) emphasize that firms shall have undervalue shares as consequences while they do not distribute dividends to investors. Reversely, Denis and Osobov (2008) argue that catering or sentiment is not a determinant of dividend policy since firms tend to pay dividends, because they are more large, more profitable, and more mature.

Furthermore, the evidences show that ownership features have a relationship with dividend policy in some countries, such as Germany (Gugler \& Yurtoglu, 2003), Norway (Bøhren, Josefsen, \& Steen, 2012), Indonesia (Saerang \& Pontoh, 2016), China (Lin, Chen, \& Tsai, 2017), and Mexico (Reyna, 2017). Gugler and Yurtoglu (2003) show that most of firms in Germany commonly have high concentrated ownership structure. They show that the interest of second largest shareholder often does not align with the main largest owner, especially to decide on dividend policy. 
Bøhren, Josefsen, and Steen (2012) find that most Norwegian firms, which are controlled by insiders, generally pay higher dividends rather than firms controlled by outsiders. Saerang and Pontoh (2016) show that Indonesian firms with individuals and/ or public ownership whether they are larger or smaller tend to distribute dividends, because of other intentions, but firms with institutional and/ or state ownership tend to distribute dividends because it is an obligation to shareholders or the term to avoid the internal conflict with shareholders. Lin, Chen, and Tsai (2017) show that Chinese firms, which are controlled by the state, tend to pay higher dividends in a circumstance they have high information asymmetry relative to firms, which are not controlled by the state. Reyna (2017) shows that most of the Mexican firms, which are dominated by family, tend to decrease dividend relative to firms, which are dominated by institutional shareholders.

\section{METHODS}

The study selected 241 listed firms with the help of purposive sampling, which is drawn from Indonesia Stock Exchange (www.idx.co.id) during the period from 2010 until 2015. The sample for this study does not include finance sector and property, real estate, and building construction sector and should meet some criteria as follows: (1) publicly issued audited financial report for the observed period; (2) providing complete performance report; and (3) firm is not a delisted firm in the capital market.

After developing the ownership structure of Saerang and Pontoh (2016), this study identifies that the ownership features for Indonesian firms are as follows: (1) single institutional and public; (2) multi-institutional, single individual, and public; (3) multi institutional, and public; (4) single institutional, single individual, and public; (5) state and public; (6) multi or single individual, single institutional, and public; (7) state, multi or single institutional, single individual, and public; and (8) multi institutional, multi-individual, and public. The study categorizes the 8 ownership features into 3 main groups based on dominant ownership in those features, which are: (1) multi-institutional; (2) single institutional; and (3) state. Table 1 pres- ents the features of ownerships and their basic features.

Table 1. The features of ownership structures

\begin{tabular}{|c|c|c|c|c|}
\hline \multirow{2}{*}{ Feature of ownerships } & \multirow{2}{*}{ Type } & \multicolumn{3}{|c|}{$\begin{array}{c}\text { Basic } \\
\text { features }\end{array}$} \\
\hline & & 1 & 2 & 3 \\
\hline Single institutional, public & 1 & - & $\mathrm{v}$ & - \\
\hline $\begin{array}{l}\text { Multi-institutional, single } \\
\text { individual, public }\end{array}$ & 2 & $\mathrm{v}$ & - & - \\
\hline Multi-institutional, public & 3 & $v$ & - & - \\
\hline $\begin{array}{l}\text { Single institutional, single } \\
\text { individual, public }\end{array}$ & 4 & - & $v$ & - \\
\hline State, public & 5 & - & - & $\mathrm{V}$ \\
\hline $\begin{array}{l}\text { Contains of multi/single } \\
\text { individual, single institutional, } \\
\text { public }\end{array}$ & 6 & - & $v$ & - \\
\hline $\begin{array}{l}\text { Contains of state, multi/single } \\
\text { institutional, single individual, } \\
\text { public }\end{array}$ & 7 & $v$ & V & - \\
\hline $\begin{array}{l}\text { Multi-institutional, multi- } \\
\text { individual, public }\end{array}$ & 8 & 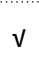 & - & - \\
\hline
\end{tabular}

Notes: This table reports the features of ownership structures of the firms. The basic features are as follows: 1 is multiinstitutional; 2 is single institutional; and 3 is state.

The dependent variable of this study is a dividend policy, which is measured by firms as dividend payers (1) and firms as non dividend payers (0). To be categorized as dividend payers, firms at least must pay dividend more than 0 (on average) to shareholders during the observed period of the study. The independent variables for this study are: (1) return on equity (symbolized by ROE); (2) earnings per share (symbolized by EPS); (3) share price (symbolized by SP); and (4) features of the ownership structures. The return on equity and earnings per share are the indicators of profitability and proxies for testing bird in the hand theory, while share price is a proxy for testing the catering theory.

The return on equity is calculated by the ratio of net income over total equity, earnings per share is calculated by ratio of net income over the outstanding shares, and share price is measured by closing market price at the end of each year, whereas the features of the ownership structures are set to dummy based on category in Table 1 . This study normalizes variables of return on equity, earnings per share, and share price with natural logarithm as they have different measurements. This study conducts the multinomial regression for hypotheses testing at the significance level of 0.05 . In order to improve the results, this study includes the 
features of the ownership structures as a moderator for variables of return on equity, earnings per share, and share price. The regression models for this study are noted as follows:

1. Multi-institutional ownership as the basic feature of ownership structures

$$
\begin{aligned}
& \gamma=\alpha+\beta_{1} \chi_{1}+\beta_{2} \chi_{2}+\beta_{3} \chi_{3}+\beta_{4} \chi_{4}+\beta_{5} \chi_{5}+ \\
& +\beta_{6} \chi_{6}+\beta_{7} \chi_{7}+\beta_{8} \chi_{1} \chi_{4}+\beta_{9} \chi_{1} \chi_{5}+\beta_{10} \chi_{1} \chi_{6}+ \\
& +\beta_{11} \chi_{1} \chi_{7}+\beta_{12} \chi_{2} \chi_{4}+\beta_{13} \chi_{2} \chi_{5}+\beta_{14} \chi_{2} \chi_{6}+ \\
& +\beta_{15} \chi_{2} \chi_{7}+\beta_{16} \chi_{3} \chi_{4}+\beta_{17} \chi_{3} \chi_{5}+\beta_{18} \chi_{3} \chi_{6}+ \\
& +\beta_{19} \chi_{3} \chi_{7}+\varepsilon
\end{aligned}
$$

where $\chi_{1}$ is return on equity; $\chi_{2}$ is earnings per share; $\chi_{3}$ is share price; $\chi_{4}$ is multi-institutional, single individual, and public (ownership feature type 2$) ; \chi_{5}$ is multi-institutional, and public (ownership feature type 3 ); $\chi_{6}$ is state, multi/ single institutional, single individual, and public (ownership feature type 7); $\chi_{7}$ is multi-institutional, multi-individual, and public (ownership feature type 8 ); $\chi_{1} \chi_{4}$ is return on equity moderated by ownership feature type $2 ; \chi_{1} \chi_{5}$ is return on equity moderated by ownership feature type 3 ; $\chi_{1} \chi_{6}$ is return on equity moderated by ownership feature type $7 ; \chi_{1} \chi_{7}$ is return on equity moderated by ownership feature type $8 ; \chi_{2} \chi_{4}$ is earnings per share moderated by ownership feature type $2 ; \chi_{2} \chi_{5}$ is earnings per share moderated by ownership feature type $3 ; \chi_{2} \chi_{6}$ is earnings per share moderated by ownership feature type 7 ; $\chi_{2} \chi_{7}$ is earnings per share moderated by ownership feature type $8 ; \chi_{3} \chi_{4}$ is share price moderated by ownership feature type $2 ; \chi_{3} \chi_{5}$ is share price moderated by ownership feature type $3 ; \chi_{3} \chi_{6}$ is share price moderated by ownership feature type $7 ; \chi_{3} \chi_{7}$ is share price moderated by ownership feature type 8 ; and $\varepsilon$ is standard error.

2. Single institutional ownership as the basic feature of ownership structures

$$
\begin{aligned}
& \gamma=\alpha+\beta_{1} \chi_{1}+\beta_{2} \chi_{2}+\beta_{3} \chi_{3}+\beta_{4} \chi_{4}+\beta_{5} \chi_{5}+ \\
& +\beta_{6} \chi_{6}+\beta_{7} \chi_{7}+\beta_{8} \chi_{1} \chi_{4}+\beta_{9} \chi_{1} \chi_{5}+\beta_{10} \chi_{1} \chi_{6}+ \\
& +\beta_{11} \chi_{1} \chi_{7}+\beta_{12} \chi_{2} \chi_{4}+\beta_{13} \chi_{2} \chi_{5}+\beta_{14} \chi_{2} \chi_{6}+ \\
& +\beta_{15} \chi_{2} \chi_{7}+\beta_{16} \chi_{3} \chi_{4}+\beta_{17} \chi_{3} \chi_{5}+\beta_{18} \chi_{3} \chi_{6}+ \\
& +\beta_{19} \chi_{3} \chi_{7}+\varepsilon
\end{aligned}
$$

where $\chi_{1}$ is return on equity; $\chi_{2}$ is earnings per share; $\chi_{3}$ is share price; $\chi_{4}$ is single institutional, and public (ownership feature type 1); $\chi_{5}$ is single institutional, single individual, and public (ownership feature type 4 ); $\chi_{6}$ is multi/single individual, single institutional, and public (ownership feature type 6); $\chi_{7}$ is state, multi/single institutional, single individual, and public (ownership feature type 7); $\chi_{1} \chi_{4}$ is return on equity moderated by ownership feature type $1 ; \chi_{1} \chi_{5}$ is return on equity moderated by ownership feature type $4 ; \chi_{1} \chi_{6}$ is return on equity moderated by ownership feature type 6 ; $\chi_{1} \chi_{7}$ is return on equity moderated by ownership feature type $7 ; \chi_{2} \chi_{4}$ is earnings per share moderated by ownership feature type $1 ; \chi_{2} \chi_{5}$ is earnings per share moderated by ownership feature type 4 ; $\chi_{2} \chi_{6}$ is earnings per share moderated by ownership feature type $6 ; \chi_{2} \chi_{7}$ is earnings per share moderated by ownership feature type $7 ; \chi_{3} \chi_{4}$ is share price moderated by ownership feature type $1 ; \chi_{3} \chi_{5}$ is share price moderated by ownership feature type $4 ; \chi_{3} \chi_{6}$ is share price moderated by ownership feature type $6 ; \chi_{3} \chi_{7}$ is share price moderated by ownership feature type 7; and $\varepsilon$ is standard error.

3. State ownership as the basic feature of ownership structures

$$
\begin{aligned}
& \gamma=\alpha+\beta_{1} \chi_{1}+\beta_{2} \chi_{2}+\beta_{3} \chi_{3}+\beta_{4} \chi_{4}+ \\
& +\beta_{5} \chi_{1} \chi_{4}+\beta_{6} \chi_{2} \chi_{4}+\beta_{7} \chi_{3} \chi_{4}+\varepsilon
\end{aligned}
$$

where $\chi_{1}$ is return on equity; $\chi_{2}$ is earnings per share; $\chi_{3}$ is share price; $\chi_{4}$ is state and public (ownership feature type 5); $\chi_{1} \chi_{4}$ is return on equity moderated by ownership feature type $5 ; \chi_{2} \chi_{4}$ is earnings per share moderated by ownership feature type 5 ; $\chi_{3} \chi_{4}$ is share price moderated by ownership feature type 5; and $\varepsilon$ is standard error.

\section{RESULT AND DISCUSSION}

\subsection{Do ownership features have a role to realize the bird in the hand?}

(2) Under condition that profitability is not moderated by ownership features, Table 2 shows that return on equity $\left(\chi_{1}\right)$ for Eq. 1 and Eq. 3 is positive and significant, which means that firms as 
dividend payers with multi-institutional ownership and dividend payers with state ownership shall pay dividends when their return on equity $\left(\chi_{1}\right)$ increases relative to firms as non-dividend payers. As for earnings per share $\left(\chi_{2}\right)$, Table 2 shows that Eq. 2 shows positive and significant value at 0.05 which means that firms as dividend payers with single institutional ownership as the basic features shall pay dividends when earnings per share $\left(\chi_{2}\right)$ increases relative to firms as nondividend payers. Based on those results, the findings imply that firms with basic features of multiinstitutional, single institutional, and state ownership generally have possibility to realize dividends to their shareholders only in case their profitability increases. Regardless of the assumption of clientele effect, those results are still consistent with bird in the hand theory, as suggested by Lintner (1956), Bhattacharya (1979), Easterbrook (1984), Denis and Osobov (2008), and Farrukh, Irshad, Khakwani, Ishaque, and Ansari (2017).

Under condition that profitability is moderated by ownership features, the findings show that bird in the hand is not fully realized, since the ownership features play the role to determine dividend policy. In Eq. 1, Table 2 shows that the results of moderated return on equity $\left(\chi_{1} \chi_{4}, \chi_{1} \chi_{5}, \chi_{1} \chi_{7}\right)$ are negative and significant. These results imply that dividend disbursement will decrease if return on equity increases, especially for firms with such features as: (1) multi-institutional, single individual, and public; (2) multi-institutional, and public; and (3) multi-institutional, multi-individual, and public. Furthermore, Table 2 shows that the results for moderated earnings per share $\left(\chi_{2} \chi_{4}, \chi_{2} \chi_{7}\right)$ in Eq. 1 are positive and significant. The results imply that dividend (bird in the hand) will be realized in case the earnings per share increases, especially for firms with ownership features: (1) multi-institutional, single individual, and public; and (2) multi-institutional, multi-individual, and public. Notice the work of Modigliani and Miller (1958), the circumstances on Eq. 1 are reasonable in assumptions when these firms retain the earnings for investment activities in preference of cost of capital and realize the dividend (or bird in the hand) through earnings per share, since the insiders have an access to attribute earnings for each share of shareholders. Also, Table 2 shows that moderated return on equity $\left(\chi_{1} \chi_{4}\right)$ in Eq.
2 is positive and significant, which implies that firms with single institutional and public ownership shall realize their dividends when profitability increases. Commonly, the results in Eq. 1 and Eq. 2 are supporting the findings of Saerang and Pontoh (2016), and Reyna (2017), where firms with institutional ownership normally pay dividends for their shareholders when profitability increases. Supporting the finding of Lin, Chen, and Tsai (2017), Table 2 shows that moderated return on equity $\left(\chi_{1} \chi_{4}\right)$ and moderated earnings per share $\left(\chi_{2} \chi_{4}\right)$ in Eq. 3 are insignificant, which implies that firms under management of state are not affected by ownership features in decision of dividend disbursements for shareholders.

Table 2. Testing of dividend policy by each basic feature of ownership structures

\begin{tabular}{|c|c|c|c|}
\hline $\begin{array}{c}\text { Independent } \\
\text { variables }\end{array}$ & Eq. 1 & Eq. 2 & Eq. 3 \\
\hline$\alpha$ & -4.686 & -3.477 & -3.647 \\
\hline$x_{1}$ & $0.541 *$ & 0.015 & $0.149 *$ \\
\hline$x_{2}$ & -0.078 & $0.151^{*}$ & 0.075 \\
\hline$x_{3}$ & $0.721^{*}$ & $0.550 *$ & $0.578^{*}$ \\
\hline$\chi_{4}$ & 3.366 & -0.257 & 25.981 \\
\hline$x_{5}$ & 1.281 & $-4.089 *$ & - \\
\hline$x_{6}$ & -24.485 & $-9.876^{*}$ & - \\
\hline$x_{7}$ & 0.798 & -25.693 & - \\
\hline$\chi_{1} X_{4}$ & $-1.819 *$ & 0.493* & -0.149 \\
\hline$\chi_{1} x_{5}$ & $-0.435^{*}$ & 0.336 & - \\
\hline$\chi_{1} \chi_{6}$ & 8.086 & 1.112 & - \\
\hline$x_{1} x_{7}$ & $-1.369^{*}$ & 8.611 & - \\
\hline$\chi_{2} X_{4}$ & $1.188^{*}$ & -0.258 & -0.075 \\
\hline$\chi_{2} \chi_{5}$ & 0.173 & -0.263 & - \\
\hline$\chi_{2} \chi_{6}$ & -5.637 & 0.790 & - \\
\hline$x_{2} x_{7}$ & $0.730^{*}$ & -5.866 & - \\
\hline$\chi_{3} \chi_{4}$ & -0.549 & 0.038 & -0.578 \\
\hline$\chi_{3} \chi_{5}$ & -0.206 & $0.725^{*}$ & \\
\hline$\chi_{3} \chi_{6}$ & 5.984 & 0.894 & - \\
\hline$x_{3} x_{7}$ & -0.018 & 6.155 & - \\
\hline
\end{tabular}

Notes: This table reports the results of multinomial regression on testing the dividend policy by each basic feature of ownership structures, where the reference category for comparison is firms as non-dividend payers (code 0 ). The dependent variable $(\gamma)$ is dividend policy measured with dummy, where firms as dividend payers are coded by 1 , and firms as non-dividend payers are coded by 0 . In Eq. $1, \chi_{1}$ is return on equity; $\chi_{2}$ is earnings per share; $\chi_{3}$ is share price; $\chi_{1}$ is multi-institutional, single individual, and public (ownership feature type 2); $\chi_{5}$ is multi-institutional, and public (ownership feature type 3); $\chi_{6}$ is state, multi/single institutional, single individual, and public (ownership feature type 7); $\chi_{7}$ is multiinstitutional, multi-individual, and public (ownership feature type 8$) ; \chi_{1} \chi_{4}$ is return on equity moderated by ownership feature type $2 ; \chi_{1} \chi_{5}$ is return on equity moderated by ownership feature type $3 ; \chi_{1} \chi_{6}$ is return on equity moderated by ownership feature type $7 ; \chi_{1} \chi_{7}$ is return on equity moderated by ownership feature type $8 ; \chi_{2} \chi_{4}$ is earnings per 
share moderated by ownership feature type $2 ; \chi_{2} \chi_{5}$ is earnings per share moderated by ownership feature type $3 ; \chi_{2} \chi_{6}$ is earnings per share moderated by ownership feature type 7 $\chi_{2} \chi_{7}$ is earnings per share moderated by ownership feature type $8 ; \chi_{3} \chi_{4}$ is share price moderated by ownership feature type 2; $\chi_{3} X_{5}$ is share price moderated by ownership feature type 3 ; $\chi_{3} \chi_{6}$ is share price moderated by ownership feature type $7 ; \chi_{3} \chi_{7}$ is share price moderated by ownership feature type 8 ; and $\varepsilon$ is standard error. In Eq. 2, $\chi_{1}$ is return on equity; $\chi_{2}$ is earnings per share; $\chi_{3}$ is share price; $\chi_{4}$ is single institutional, and public (ownership feature type 1 ); $\chi_{5}$ is single institutional, single individual, and public (ownership feature type 4 ); $\chi_{6}$ is multi/ single individual, single institutional, and public (ownership feature type 6); $\chi_{7}$ is state, multi/single institutional, single individual, and public (ownership feature type 7); $\chi_{1} \chi_{4}$ is return on equity moderated by ownership feature type $1 ; \chi_{1} \chi_{5}$ is return on equity moderated by ownership feature type 4 $\chi_{1} X_{6}$ is return on equity moderated by ownership feature type 6 $\chi_{1} \chi_{7}$ is return on equity moderated by ownership feature type 7; $\chi_{2} \chi_{1}$ is earnings per share moderated by ownership feature type 1; $\chi_{2} \chi_{5}$ is earnings per share moderated by ownership feature type $4 ; \chi_{2} \chi_{6}$ is earnings per share moderated by ownership feature type $6 ; x_{2} x_{7}$ is earnings per share moderated by ownership feature type $7 ; \chi_{3} \chi_{4}$ is share price moderated by ownership feature type $1 ; \chi_{3} \chi_{5}$ is share price moderated by ownership feature type $4 ; \chi_{3} \chi_{6}$ is share price moderated by ownership feature type $6 ; \chi_{3} x_{7}$ is share price moderated by ownership feature type 7; and $\varepsilon$ is standard error. In Eq. 3, $\chi$ is return on equity; $\chi_{2}$ is earnings per share; $\chi_{3}$ is share price; $\chi_{1}$ is state and public (ownership feature type 5); $\chi_{1} \chi_{4}$ is return on equity moderated by ownership feature type $5 ; \chi_{2} \chi_{4}$ is earnings per share moderated by ownership feature type $5 ; \chi_{3} \chi_{4}$ is share price moderated by ownership feature type 5 ; and $\varepsilon$ is standard error. The figure of ${ }^{\star}$ indicates statistical significance at 0.05 .

\subsection{Do ownership features have a role to cater the shareholders?}

Table 2 shows that the results of share price $\left(\chi_{3}\right)$ without being moderated by ownership features in Eq. 1, Eq. 2, and Eq. 3 are positive and significant. These results indicate that firms as dividend payers shall pay dividends when share price is increasing relative to firms as non-dividend payers. Those results also confirm that catering theory is fit for these firms, as suggested by Baker and Wurgler (2004a, 2004b). Consistent with Dreman and Lufkin (2000), Li and Zhao (2008), Polk and Sapienza (2009), Pontoh (2015), and Budiarso and Pontoh (2016), those results imply that firms utilize the investor's psychology with dividend announcement and so investors put high demand on firm shares in capital market.
Under condition that share price is moderated by ownership features, Table 2 shows that catering theory is not fit for Eq. 1 and Eq. 3, which is inconsistent with Dreman and Lufkin (2000), Baker and Wurgler (2004a, 2004b), Li and Zhao (2008), Polk and Sapienza (2009), Pontoh (2015), and Budiarso and Pontoh (2016). These results imply that firms with multi-institutional and state ownership are not affected by market reaction, so they shall not cater the shareholders when the shares are overvalued. Reversely, the result of moderated share price $\left(\chi_{3} \chi_{5}\right)$ in Eq. 2 shows that catering theory is fit for firms with single institutional, single individual, and public, ownership which implies that they shall cater the shareholders with dividends if they are overvaluing the firm shares in capital market. On this result, the finding is consistent with Dreman and Lufkin (2000), Baker and Wurgler (2004a, 2004b), Li and Zhao (2008), Polk and Sapienza (2009), Pontoh (2015), and Budiarso and Pontoh (2016). Table 3 presents the summary of theory implication for each features of ownerships.

Table 3. Theory implication for each features of ownership structures

\begin{tabular}{|c|c|c|c|c|c|c|}
\hline \multirow{2}{*}{$\begin{array}{l}\text { Feature of } \\
\text { ownerships }\end{array}$} & \multirow{2}{*}{ Type } & \multicolumn{3}{|c|}{$\begin{array}{c}\text { Basic } \\
\text { features }\end{array}$} & \multirow{2}{*}{$\begin{array}{l}\text { Bird } \\
\text { in the } \\
\text { hand }\end{array}$} & \multirow{2}{*}{ Catering } \\
\hline & & 1 & 2 & 3 & & \\
\hline $\begin{array}{l}\text { Single institutional, } \\
\text { public }\end{array}$ & 1 & - & $v$ & - & $\mathrm{V}$ & - \\
\hline $\begin{array}{l}\text { Multi-institutional, } \\
\text { single individual, public }\end{array}$ & 2 & $v$ & - & - & $\mathrm{V}$ & - \\
\hline $\begin{array}{l}\text { Multi-institutional, } \\
\text { public }\end{array}$ & 3 & $v$ & & - & - & - \\
\hline $\begin{array}{l}\text { Single institutional, } \\
\text { single individual, public }\end{array}$ & 4 & - & V & - & - & $\mathrm{V}$ \\
\hline State, public & 5 & - & & $\mathrm{v}$ & - & - \\
\hline $\begin{array}{l}\text { Contains of multi/ } \\
\text { single individual, single } \\
\text { institutional, public }\end{array}$ & 6 & - & $v$ & - & - & - \\
\hline $\begin{array}{l}\text { Contains of state, multi/ } \\
\text { single institutional, } \\
\text { single individual, public }\end{array}$ & 7 & $v$ & $v$ & - & - & - \\
\hline $\begin{array}{l}\text { Multi-institutional, } \\
\text { multi-individual, public }\end{array}$ & 8 & $\mathrm{~V}$ & - & - & $\mathrm{V}$ & - \\
\hline
\end{tabular}

Notes: This table reports the features of ownership structures of the firms. The basic features are as follows: 1 is multiinstitutional; 2 is single institutional; and 3 is state.

\section{CONCLUSION}

The issues around dividend disbursement have become long discussions for many studies in perspective of bird in the hand theory and catering theory. With the aim to give empirical evidence, this study identifies that firms in Indonesia have many features in ownership structures, and relates the facts to those 
theories. Commonly, under condition that dividend policy is not moderated by ownership features, the firms with multi-institutional, single institutional, and state ownership shall disburse dividend to shareholders when condition when profitability and share price increase. In other words, dividend policy for these firms is fit with bird in the hand theory and catering theory.

More specifically, the findings show that dividend policy for firms with features of (1) multi-institutional, single individual, and public; (2) multi-institutional, multi-individual, and public; and (3) single institutional, and public is fit with bird in the hand theory. Moreover, this study finds that firms with features of multi-institutional and state ownership are not fit with catering theory, which means that these firms shall not cater shareholders with dividends in case their shares are overvalued. Reversely, firms with features of single institutional, single individual, and public ownership shall cater shareholders with dividends when firm shares in the capital market are overvalued. Uniquely, the firms that were managed by state are not affected by ownership features, which implies that dividend policy for this firm is not fit both in the context of bird in the hand theory and catering theory in realizing dividends for shareholders.

\section{REFERENCES}

1. Aharony, J., \& Swary, I. (1980). Quarterly dividend and earnings announcements and stockholders' returns: An empirical analysis. The Journal of Finance, 35(1), 1-12. https://doi. org/10.1111/j.1540-6261.1980 tb03466.x

2. Al-Yahyaee, K. H., Pham, T. M., \& Walter, T. S. (2011). The information content of cash dividend announcements in a unique environment. Journal of Banking and Finance, 35(3), 606-612. https://doi.org/10.1016/j. jbankfin.2010.03.004

3. Baker, M., \& Wurgler, J. (2004a). A catering theory of dividends. The Journal of Finance, 59(3), 11251165. Retrieved from https://www. jstor.org/stable/3694732

4. Baker, M., \& Wurgler, J. (2004b). Appearing and disappearing dividends: the link to catering incentives. Journal of Financial Economics, 73(2), 271-288. https://doi.org/10.1016/j.jfineco.2003.08.001

5. Baker, M., \& Wurgler, J. (2007). Investor sentiment in the stock market. The Journal of Economic Perspectives, 21(2), 129-151. Retrieved from http://www.nber. org/papers/w13189

6. Bhattacharya, S. (1979). Imperfect information, dividend policy, and "the bird in the hand" fallacy.
The Bell Journal of Economics, 10(1), 259-270. https://doi. org/10.2307/3003330

7. Bøhren, Ø., Josefsen, M. G., \& Steen, P. E. (2012). Stakeholder conflicts and dividend policy. Journal of Banking \& Finance, 36, 2852-2864. http://dx.doi. org/10.1016/j.jbankfin.2012.06.007

8. Budiarso, N. S., \& Pontoh, W. (2016). Firm's dividend decision in Indonesia: cater or mature? Journal of Life Economics, 3(3), 53-66. https://doi.org/10.15637/ jlecon.139

9. Budiarso, N. S. (2017). Propensity to pay dividend: testing for life cycle and free cash flow theories. Journal of Accounting, Finance And Auditing Studies, 3(2), 1-15. Retrieved from https://www.jafas.org

10. Denis, D. J., \& Osobov, I. (2008). Why do firms pay dividends? International evidence on the determinants of dividend policy. Journal of Financial Economics, 89, 62-82. https://doi.org/10.1016/j. jfineco.2007.06.006

11. Dreman, D. N., \& Lufkin, E. A. (2000). Investor overreaction: evidence that its basis is psychological. The Journal of Psychology and Financial Markets, 1(1), 61-75. https:// dx.doi.org/10.1207/S15327760JPFM0101_06
12. Easterbrook, F. H. (1984). Two agency-cost explanations of dividends. The American Economic Review, 74(4), 650-659. Retrieved from https://www.jstor. org/stable/1805130

13. Farrukh, K., Irshad, S., Khakwani, M. S., Ishaque, S., \& Ansari, N. (2017). Impact of dividend policy on shareholders wealth and firm performance in Pakistan. Cogent Business \& Management, 4, 1-11. https://doi.org/10.1080/23311975. 2017.1408208

14. Gugler, K. (2003). Corporate governance, dividend payout policy, and the interrelation between dividends, $\mathrm{R} \& \mathrm{D}$, and capital investment. Journal of Banking \& Finance, 27(7), 1297 1321. https://doi.org/10.1016/ S0378-4266(02)00258-3

15. Gugler, K., \& Yurtoglu, B. B. (2003). Corporate governance and dividend pay-out policy in Germany. European Economic Review, 47(4), 731-758. https:// doi.org/10.1016/S00142921(02)00291-X

16. Hui, B., \& Li, P. (2014). Does investor sentiment predict stock returns? The evidence from Chinese Stock Market. Journal of Systems Science and Complexity, 27(1), 130-143. https://doi. org/10.1007/s11424-013-3291-y 
17. La Porta, R., De Silanes, F. L., Shleifer, A., \& Vishny, R. W. (2000). Agency problems and dividend policies around the world. The Journal of Finance, 55(1), 1-33. https://doi. org/10.1111/0022-1082.00199

18. Li, W., \& Lie, E. (2006). Dividend changes and catering incentives. Journal of Financial Economics, 80(2), 293-308. https://doi. org/10.1016/j.jfineco.2005.03.005

19. Li, K., \& Zhao, X. (2008). Asymmetric information and dividend policy. Financial Management, 37(4), 673-694 https://doi.org/10.1111/j.1755053X.2008.00030.x

20. Lin, T. J., Chen, Y. P., \& Tsai, H. F. (2017). The relationship among information asymmetry, dividend policy and ownership structure. Finance Research Letters, 20 1-12. http://dx.doi.org/10.1016/j. frl.2016.06.008

21. Lintner, J. (1956). Distribution of incomes of corporations among dividends, retained earnings, and taxes. The American Economic Review, 46(2), 97-113. Retrieved from http://www.jstor.org/stable/1910664

22. Modigliani, F., \& Miller, M. H. (1958). The cost of capital, corporation finance and the theory of investment. The American Economic Review, 48(3), 261-297. Retrieved from https:// www.jstor.org/stable/1809766

23. Ozuomba, C. N., Anichebe, A. S., \& Okoye, P. V. C. (2016). The effect of dividend policies on wealth maximization - a study of some selected plcs. Cogent Business \& Management, 3(1), 1-15. https:// dx.doi.org/10.1080/23311975.201 6.1226457

24. Polk, C., \& Sapienza, P. (2009). The stock market and corporate investment: A test of catering theory. The Review of Financial Studies, 22(1), 187-217. https:// dx.doi.org/10.1093/rfs/hhn030
25. Pontoh, W. (2015). Signaling, bird in the hand, and catering effect in Indonesia. Journal of Life Economics, 2(3), 1-24. https://doi. org $/ 10.15637 /$ jlecon. 80

26. Reyna, J. M. S. M. (2017). Ownership structure and its effect on dividend policy in the Mexican context. Contaduría y Administración, 62, 1199-1213. https://dx.doi.org/10.1016/j. cya.2015.12.006

27. Saerang, D. P. E., \& Pontoh, W. (2016). The role of ownership on behavior of dividend payers. Journal of Life Economics, 3(4), 59-68. https://doi.org/10.15637/ jlecon.156

28. Wei, Z., Wu, S., Li, C., and Chen, W. (2011). Family control, institutional environment and cash dividend policy: Evidence from China. China Journal of Accounting Research, 4(1-2), 29-46. https://doi.org/10.1016/j. cjar.2011.04.001 